\title{
Perbedaan Equity Crowdfunding Dan Initial Public Offering (IPO) Dalam Hukum Pasar Modal Indonesia
}

\author{
Widya Rahmadhani \\ Magister Hukum Ekonomi, Fakultas Hukum Universitas Indonesia \\ Email Korespondensi: widya.rhmdn@gmail.com
}

\begin{abstract}
Equity Crowdfunding is newly known in Indonesia. Indonesia’s Financial Services Authority passed new regulation that regulating Equity Crowdfunding through Indonesia Financial Services Authorities Rule Number 37/POJK.04/2018 regarding Equity Crowdfunding. Equity Crowdfunding concept considered similar to Initial Public Offering (IPO). Further, this research objective is to analyze Equity Crowdfunding from Indonesia's Capital Market Law Perspective to find out if Equity Crowdfunding is remarkably similar to Initial Public Offering (IPO). This research is a normative study using documentary studies in the form of secondary data. The research was found that although there are similarities on the main concept between Equity Crowdfunding and Initial Public Offering, the two has distinguishing power. The research also found that there are some risks awaiting on the Equity Crowdfunding scheme.
\end{abstract}

Keywords: Equity Crowdfunding, Crowdfunding, Initial Public Offering, Capital Market Law, Financial Technology, Fintech.

\begin{abstract}
Abstrak. Equity Crowdfunding merupakan bentuk alternatif pendanaan baru yang dikenal di Indonesia. Otoritas Jasa Keuangan mengesahkan peraturan terkat dengan Layanan Urun Dana Penawaran Saham Berbasis Teknologi Informasi (Equity Crowdfunding) melalui POJK No. 37/POJK.04/2018 yang mengatur mengenai skema Equity Crowdfunding. Konsep Equity Crowdfunding ini dianggap mirip dengan Penawaran Umum atau Initial Public Offering (IPO). Berkaitan dengan hal tersebut, Penelitian ini dimaksudkan untuk menganalisis Equity Crowdfunding dalam Perspektif Hukum Pasar Modal Indonesia apakah benar-benar dapat dipersamakan dengan Penawaran Umum. Penelitian ini merupakan penelitian normatif yang menggunakan studi dokumen berupa data sekunder. Hasil penelitian menemukan bahwa meskipun ada kemiripan Equity Crowdfunding dengan Penawaran Umum pada konsep utamanya, terdapat beberapa hal yang menjadi daya pembeda antara keduanya. Hasil penelitian juga menemukan adanya risiko-risiko yang menunggu dalam skema Equity Crowdfunding.
\end{abstract}

Kata Kunci: Layanan Urun Dana Saham, Layanan Urun Dana, Penawaran Umum, Hukum Pasar Modal, Teknologi Keuangan

\section{PENDAHULUAN}

\section{Latar Belakang}

Dunia saat ini sudah memasuki era digital yang mengedepankan perkembangan dalam bidang teknologi. Optimalisasi penggunaan teknologi dalam berbagai bidang kehidupan dapat membantu terwujudnya efektivitas dan efisiensi sehingga memudahkan hidup manusia. Salah satu penerapan teknologi yang sangat penting adalah di bidang keuangan, atau yang dikenal dengan financial technology atau FinTech. Financial Technology (FinTech) merupakan suatu kolaborasi antara teknologi dan fitur keuangan atau dapat juga diartikan sebagai pembaruan pada sektor finansial dengan sentuhan teknologi. Salah satu tipe financial technology adalah Equity Crowdfunding, yang seharusnya, secara konsep dapat dipersamakan dengan Initial Public Offering (IPO) dalam hukum Pasar Modal.

Pada tahun 2018, Otoritas Jasa Keuangan Indonesia mengeluarkan Peraturan Otoritas Jasa Keuangan Nomor 37/POJK.04/2018 tentang Layanan Urun Dana Melalui Penawaran Saham Berbasis Teknologi Informasi atau yang dikenal dengan Equity Crowdfunding. Pada bagian konsiderans peraturan tersebut, pertimbangan dari Otoritas Jasa Keuangan menyusun peraturan mengenai Equity Crowdfunding adalah untuk mendukung pelaku usaha pemula (start up company) untuk berkontribusi terhadap perekonomian nasional melalui penyediaan alternatif sumber pendanaan berbasis teknologi informasi. Selain itu, peraturan ini dibentuk untuk memberikan kepastian hukum dan perlindungan bagi pihak yang terlibat dalam kegiatan Layanan Urun Dana melalui 
Penawaran Saham berbasis Teknologi Informasi (Equity Crowdfunding).

Berdasarkan pada Peraturan Otoritas Jasa Keuangan Nomor 37/POJK.04/2018 tentang Layanan Urun Dana Melalui Penawaran Saham Berbasis Teknologi Informasi (Equity Crowdfunding), yang dimaksud dengan:

"Layanan Urun Dana Melalui Penawaran Saham Berbasis Teknologi Informasi (Equity Crowdfunding) yang selanjutnya disebut Layanan Urun Dana adalah penyelenggaraan layanan penawaran saham yang dilakukan oleh penerbit untuk menjual saham secara langsung kepada pemodal melalui jaringan sistem elektronik yang bersifat terbuka."

Dengan dikeluarkannya Peraturan Otoritas Jasa Keuangan Nomor 37 Tahun 2018 mengenai Equity Crowdfunding, berdasarkan data terbaru dari Otoritas Jasa Keuangan per 31 Desember 2019, sudah terdapat 3 (tiga) perusahaan yang telah mengantongi izin usaha penyelenggara Equity Crowdfunding di Indonesia, yaitu PT Santara Daya Inspiratama dengan platformnya Santara dan alamat website www.santara.co.id, PT Investasi Digital Nusantara dengan nama platform Bizhare dan situs website www.bizhare.id, serta PT Crowddana Teknologi Indonusa dengan nama platform Crowddana dan situs website www.crowddana.id.

Adapun Initial Public Offering (IPO) atau Penawaran Umum berdasarkan UndangUndang No. 8 Tahun 1995 tentang Pasar Modal adalah: "kegiatan penawaran Efek yang dilakukan oleh Emiten untuk menjual Efek kepada masyarakat berdasarkan tata cara yang diatur dalam Undang-Undang ini dan peraturan pelaksanaannya." Tujuan dari Initial Public Offering (IPO) adalah untuk mendapatkan dana dari masyarakat guna membiayai kegiatan perusahaan dengan suatu harapan akan tercipta kinerja perusahaan yang lebih baik.

Berdasarkan definisi Initial Public Offering (IPO) atau Penawaran Umum yang diberikan oleh Undang-Undang Nomor 8 Tahun 1995 serta Equity Crowdfunding pada Peraturan Otoritas Jasa Keuangan Nomor 37/POJK.04/2018, secara maksud, Equity
Crowdfunding dan Initial Public Offering (IPO) pada intinya merupakan suatu kegiatan penawaran saham kepada masyarakat untuk mendapatkan dana dari masyarakat. Namun, kemudian muncul pertanyaan terkait dengan perbedaan antara Equity Crowdfunding dengan Initial Public Offering (IPO).

\section{Perumusan Masalah}

Artikel ini membahas perbedaan Equity Crowdfunding dan Initial Public Offering (IPO). Untuk membahas hal tersebut, akan dijelaskan terlebih dahulu pengaturan Equity Crowdfunding dan Initial Public Offering (IPO) di Indonesia. Tulisan ini kemudian akan menguraikan dan membahas mengenai perbedaan Equity Crowdfunding dengan Initial Public Offering (IPO).

\section{METODE PENELITIAN}

Metode penelitian yang digunakan untuk menjawab permasalahan dalam artikel ini menggunakan metode penelitian hukum normatif. Penelitian hukum normatif merupakan penelitian yang dilakukan dengan cara meneliti bahan pustaka atau data sekunder. Dalam melakukan penelitian ini, Penulis menggunakan metode studi pustaka dengan studi dokumen terhadap data sekunder. Adapun data sekunder yang dipergunakan dalam penelitian ini berupa buku, berita dan peraturan perundang-undangan. Peraturan perundang-undangan yang dipergunakan oleh Penulis adalah Peraturan Otoritas Jasa Keuangan Nomor 37/POJK.04/2018 tentang Layanan Urun Dana Melalui Penawaran Saham Berbasis Teknologi Informasi (Equity Crowdfunding) serta Undang-Undang Nomor 8 Tahun 1995 tentang Pasar Modal.

\section{HASIL DAN PEMBAHASAN}

\section{A. Pengaturan Equity Crowdfunding dalam Peraturan Otoritas Jasa Keuangan Nomor 37/POJK.04/2018}

Pada Equity Crowdfunding, terdapat 2 (dua) pihak besar yang terlibat di dalamnya, yakni pihak Penyelenggara dan Pengguna Layanan Urun Dana. Penyelenggara Layanan Urun Dana merupakan badan hukum Indonesia yang menyediakan, mengelola, dan mengoperasikan Layanan Urun Dana dan 
Pengguna Layanan Urun Dana adalah penerbit dan pemodal. Penerbit merupakan badan hukum Indonesia yang berbentuk perseroan terbatas yang menawarkan saham melalui Penyelenggara dan Pemodal adalah pihak yang melakukan pembelian saham Penerbit melalui Penyelenggara.

\section{Penyelenggara Layanan Urun Dana}

Berdasarkan pada Pasal 7, pihak yang berperan sebagai Penyelenggara dalam skema Layanan Urun Dana wajib memiliki izin usaha dari Otoritas Jasa Keuangan. Penyelenggara juga harus merupakan Penyelenggara yang terdaftar sebagai Penyelenggara Sistem Elektronik pada Kementerian Komunikasi dan Informatika (Kominfo). Adapun bentuk badan hukum Penyelenggara berdasarkan Pasal 10 dapat berbentuk Perseroan Terbatas atau Koperasi, dimana, Perseroan Terbatas yang dimaksud dapat berupa Perusahaan Efek yang telah memperoleh persetujuan dari Otoritas Jasa Keuangan untuk melakukan kegiatan lain sebagai Penyelenggara Layanan Urun Dana. Adapun Koperasi yang dimaksud hanya terbatas pada jenis koperasi Jasa.

Pada Pasal 12 diatur bahwa Penyelenggara harus memiliki modal disetor minimal Rp 2.500.000.000,00 (dua miliar lima ratus juta rupiah) saat mengajukan permohonan perizinan ke Otoritas Jasa Keuangan. Untuk Penyelenggara yang merupakan Perusahaan Efek, harus memiliki modal sendiri paling sedikit $\mathrm{Rp}$ 2.500.000.000,00 (dua miliar lima ratus juta rupiah) saat mengajukan permohonan perizinan. Peraturan Otoritas Jasa Keuangan juga mengatur pada Pasal 13 mengenai Kualifikasi Sumber Daya Manusia sebagai pihak Penyelenggara, dimana:

"Penyelenggara wajib memiliki:

a. sumber daya manusia yang memiliki keahlian dan/atau latar belakang di bidang Teknologi Informasi; dan

b. sumber daya manusia yang memiliki keahlian untuk melakukan reviu terhadap Penerbit.",

Terdapat beberapa hal yang wajib dilakukan oleh Penyelenggara, secara garis besar sebagaimana disebutkan pada Pasal 16 ayat (1), yaitu:
1. melaksanakan reviu terhadap Penerbit, paling sedikit terkait legalitas Penerbit dan dokumen dan/atau informasi yang wajib disampaikan oleh Penerbit kepada Penyelenggara;

2. mengunggah dokumen dan/atau informasi wajib tersebut secara online melalui situs web Penyelenggara;

3. memuat informasi dalam situs web Penyelenggara dalam hal terdapat perubahan material yang dapat mempengaruhi keputusan investasi Pemodal terkait dokumen dan/atau informasi wajib;

4. memastikan pelaksanaan penawaran saham melalui Layanan Urun Dana sampai dengan terpenuhinya seluruh hak dan kewajiban Pengguna;

5. melaporkan pelanggaran yang dilakukan Penerbit selama masa penawaran dan pelanggaran atas kewajiban Penerbit yang berkaitan langsung dengan berakhirnya masa penawaran kepada Otoritas Jasa Keuangan;

6. melaksanakan program pendidikan bagi Pengguna;

7. menyimpan dokumen dan/atau informasi yang disampaikan Penerbit dalam jangka waktu penyimpanan dokumen sebagaimana dimaksud dalam UndangUndang mengenai dokumen perusahaan;

8. memastikan batas penghimpunan dana melalui Layanan Urun Dana oleh setiap Penerbit tidak terlampaui;

9. menyediakan fasilitas komunikasi secara online antara Pemodal dengan Penerbit;

10. memuat dalam situs web Penyelenggara mengenai risiko, paling sedikit meliputi risiko:

1. usaha;

2. investasi;

3. likuiditas;

4. kelangkaan pembagian dividen;

5. dilusi kepemilikan saham; dan

6. kegagalan Sistem Elektronik;

11. memiliki sistem untuk memastikan hanya Pemodal yang telah memberikan konfirmasi mengenai pemenuhan persyaratan Pemodal yang dapat berinvestasi melalui Layanan Urun Dana; 
12. menggunakan nama domain Indonesia;

13. menyediakan layanan pengaduan sengketa melalui fungsi internal dispute resolution;

14. memuat dalam situs web Penyelenggara mengenai biaya dan pengeluaran lainnya yang dikenakan atau dibebankan kepada Pengguna;

15. mempunyai mekanisme pengembalian dana dalam hal penawaran saham melalui Layanan Urun Dana batal demi hukum; dan

16. menggunakan Gedung atau ruangan kantor baik yang dimiliki sendiri atau berdasarkan perjanjian sewa Gedung atau ruangan.

\section{Penerbit Layanan Urun Dana}

Penerbit dalam Layanan Urun Dana berdasarkan Pasal 33 harus berbentuk Perseroan Terbatas. Penerbit berdasarkan Pasal 34 tidak boleh merupakan:

1. perusahaan yang dikendalikan baik langsung maupun tidak langsung oleh suatu kelompok usaha atau konglomerasi;

2. perusahaan terbuka atau anak perusahaan terbuka; dan

3. perusahaan dengan kekayaan lebih dari Rp 10.000.000.000,00 (sepuluh miliar rupiah), tidak termasuk tanah dan bangunan.

Penerbit memiliki beberapa kewajiban yang tertuang pada Peraturan Otoritas Jasa Keuangan mengenai Equity Crowdfunding, yaitu:

1. Menyerahkan dokumen dan/atau informasi wajib kepada Penyelenggara mengenai legalitas Penerbit, jumlah dana yang akan dihimpun dalam penawaran saham dan tujuan penggunaan dana hasil penawaran saham, jumlah minimum dana yang harus diperoleh dalam penawaran saham, risiko utama yang dihadapi Penerbit dan risiko kemungkinan tidak likuidnya saham yang ditawarkan, rencana bisnis Penerbit, perizinan, kebijakan dividen, laporan keuangan yang paling rendah disusuh berdasarkan standar akutansi tanpa akuntabilitas publik, dan mekanisme penetapan harga saham (Pasal 35 ayat 1).

2. Wajib menyampaikan laporan tahunan kepada Otoritas Jasa Keuangan dan mengumumkan kepada masyarakat melalyi situs web Penyelenggara dan/atau situs web Penerbit paling lama 6 (enam) bulan setelah tahun buku berakhir (Pasal 39 ayat 1$)$.

3. Wajib mencatatkan kepemilikan saham Pemodal dalam daftar pemegang saham (Pasal 41).

\section{Pemodal dalam Layanan Urun Dana}

Peraturan Otoritas Jasa Keuangan mengenai Equity Crowdfunding pada Pasal 42 ayat (1) mengatur persyaratan bagi Pemodal yang dapat membeli saham melalui Layanan Urun Dana yakni pihak yang memiliki kemampuan untuk membeli saham Penerbit, memiliki kemampuan analisis risiko terhadap saham Penerbit, dan memenuhi kriteria Pemodal yang tertuang pada Peraturan Otoritas Jasa Keuangan.

Mengenai kriteria Pemodal dituangkan pada Pasal 42 ayat (2) bahwa yang dimaksud dengan Pemodal yaitu:

a. setiap Pemodal dengan penghasilan sampai dengan Rp 500.000.000,00 (lima ratus juta rupiah) per tahun, dapat membeli saham melalui Layanan Urun Dana paling banyak sebesar 5\% (lima persen) dari penghasilan per tahun; dan

b. setiap Pemodal dengan penghasilan lebih dari Rp 500.000.000,00 (lima ratus juta rupiah) per tahun, dapat membeli saham melalui Layanan Urun Dana paling banyak sebesar $10 \%$ (sepuluh persen) dari penghasilan per tahun.

Namun, bila Pemodal merupakan badan hukum dan pihak yang memiliki pengalaman berinvestasi di Pasar Modal yang dibuktikan dengan kepemilikan rekening Efek paling sedikit 2 (dua) tahun sebelum penawaran saham, maka Pemodal dibebaskan dari kriteria dan batasan pembelian saham di atas.

\section{B. Penawaran Saham dalam Equity Crowdfunding}

Berdasarkan Pasal 24, Penerbit hanya dapat menawarkan saham melalui 1 (satu) Penyelenggara dalam waktu yang bersamaan. Adapun batas maksimum penghimpunan dana melalui Layanan Urun Dana oleh setiap Penerbit dalam jangka waktu 12 (dua belas) bulan paling banyak adalah sebesar Rp 10.000.000.000,00 (sepuluh miliar rupiah) dan dapat dilakukan dalam 1 (satu) kali penawaran 
atau lebih. Masa penawaran saham berdasarkan Pasal 27 dilakukan paling lama 60 (enam puluh) hari.

Berdasarkan Pasal 29, pembelian saham oleh Pemodal dalam penawaran saham dalam Layanan Urun Dana dilakukan dengan menyetorkan sejumlah dana pada escrow account sesuai perjanjian penyelenggaraan Layanan Urun Dana. Dana dari Pemodal wajib diserahkan oleh Penyelenggara kepada Penerbit paling lambat 21 (dua puluh satu) hari kerja setelah berakhirnya masa penawaran saham.

Bila saham yang diterbitkan merupakan saham tanpa warkat, berdasarkan pada Pasal 38 ayat (1), Penerbit wajib mencatatkan sahamnya di kustodian yang disepakati oleh Penyelenggara dan Penerbit. Bukti kepemilikan yang diperoleh oleh Pemodal dalam hal saham yang diterbitkan adalah saham tanpa warkat adalah berupa catatan kepemilikan saham yang terdapat dalam rekening Efek pada kustodian.

\section{Initial Public Offering (IPO)}

Initial Public Offering (IPO) atau yang diartikan sebagai penawaran umum perdana atau go public merupakan gejala yang mulai dikenal di Indonesia sejak akhir tahun 1980 dan mulai memasuki masa popular di awal tahun 1990. Istilah penawaran umum perdana saham adalah kegiatan emiten (pihak yang melakukan penawaran umum) untuk menjual efek yang dikeluarkannya kepada masyarakat maupun investor, yang diharapkan akan membeli dan memberikan pemasukan dana guna pengembangan usaha, membayar hutang, maupun kegiatan lainnya yang diinginkan oleh emiten tersebut.

Manfaat suatu perusahaan melakukan penawaran umum (go public):

a. Dapat memperoleh dana yang relatif besar dan diterima sekaligus;

b. Proses relatif mudah;

c. Pembagian dividen berdasarkan keuntungan;

d. Penyertaan masyarakat biasanya tidak masuk dalam manajemen; e. Perusahaan dituntut lebih terbuka, sehingga hal ini dapat memacu perusahaan untuk meningkatkan profesionalisme;

f. Memberikan kesempatan kepada masyarakat untuk turut serta memiliki saham perusahaan, sehingga dapat mengurang kesenjangan sosial;

g. Emiten akan lebih dikenal oleh masyarakat (go public merupakan media promosi) secara gratis;

h. Memberikan kesempatan bagi koperasi dan karyawan perusahaan untuk membeli saham.

\section{i. Syarat Perusahaan Melakukan Initial Public Offering (IPO)}

Pada Keputusan Menteri Keuangan Republik Indonesia No. 859/KMK.01/1989 tentang emisi efek di bursa dan peraturan pelaksanaan emisi dan perdagangan saham yang tercantum dalam keputusan BAPEPAM No. 011/PM/1987, persyaratan yang harus dipenuhi dalam rangka melakukan Initial Public Offering (IPO) adalah sebagai berikut:

a. Perusahaan berbadan hukum Perseroan Terbatas (PT);

b. PT yang telah beroperasi sekurangkurangnya 12 (dua belas) bulan;

c. Bertempat kedudukan di Indonesia;

d. Memiliki aktiva bersih berwujud sekurangkurangnya Rp 5.000.000.000,00 (lima miliar Rupiah) dengan laporan keuangan audit tahun buku terakhir memperoleh opini "Wajar Tanpa Pengecualian" dari akuntan publik yang terdaftar di BAPEPAM;

e. Menjual sekurang-kurangnya 50 (lima puluh) juta saham atau 35\% (tiga puluh lima) persen dari jumlah saham yang diterbitkan (mana yang lebih kecil) dan jumlah pemegang saham publik sekurangkurangnya 500 (lima ratus) pihak, dapat menjadi perusahaan publik yang sahamnya diperdagangkan di Bursa Efek Indonesia (BEI);

f. Masa beroperasi dalam usaha yang utama yang nilainya sama, 6 (enam) bulan penuh berturut-turut;

g. Laporan keuangan audit minimal 12 (dua belas) bulan; dan 
h. Nilai aktiva bersih minimal Rp 5.000.000.000,00 (lima miliar Rupiah).

\section{ii. Tahapan Initial Public Offering (IPO)}

Proses penawaran umum dapat dikelompokkan menjadi 4 tahapan, sebagai berikut:

\section{Tahapan Persiapan Awal dan Persiapan Dokumen}

Tahapan ini merupakan tahap awal dalam persiapan segala sesuatu yang berkaitan dengan proses penawaran umum. Tahap yang paling awal, perusahaan akan menerbitkan saham terlebih dahulu mengadakan Rapat Umum Pemegang Saham (RUPS) untuk meminta persetujuan para pemegang saham dalam rangka Penawaran Umum Saham. Setelah disetujui, emiten melakukan penunjukan penjamin emisi serta lembaga dan profesi penunjang pasar, yakni:

a. Penjamin Emisi (underwriter), yang merupakan pihak yang paling banyak keterlibatannya dalam membantu Emiten dalam rangka penerbitan saham. Kegiatan yang dilakukan Penjamin Emisi yaitu dimulai dari menyiapkan berbagai dokumen, membantu menyiapkan prospectus, dan memberikan penjaminan atas penerbitan.

b. Akuntan Publik (Auditor Independent), bertugas melakukan audit atau pemeriksaan atas laporan keuangan calon Emiten.

c. Penilai untuk melakukan penilaian terhadap aktiva tetap perusahaan dan menentukan nilai wajar dari aktiva tetap tersebut.

d. Konsultan Hukum untuk memberikan pendapat dari segi hukum (legal opinion).

e. Notaris untuk membuat akta-akta perubahan Anggaran Dasar, akta perjanjianperjanjian dalam rangka penawaran umum dan juga notulen-notulen rapat.

\section{Penyampaian Permohonan Perjanjian Pendahuluan Pencatatan Saham ke Bursa Efek Indonesia}

Untuk menjadi perusahaan publik yang sahamnya dicatatkan dan diperdagangkan di Bursa Efek Indonesia, perusahaan perlu mengajukan permohonan untuk mencatatkan saham, dilengkapi dengan dokumen-dokumen yang dipersyaratkan, antara lain profil perusahaan, laporan keuangan, opini hukum, proyeksi keuangan, dan lain-lain. Selain itu, Perusahaan perlu menyampaikan permohonan pendaftaran saham untuk dititipkan secara kolektif (scripless) di Kustodian Sentral Efek Indonesia (KSEI). Apabila Perusahaan telah memenuhi persyaratan yang ditentukan, dalam waktu maksimal 10 (sepuluh) Hari Bursa setelah dokumen lengkap, Bursa Efek Indonesia akan memberikan persetujuan prinsip berupa Perjanjian Pendahuluan Pencatatan Saham kepada Perusahaan.

\section{Penyampaian Pernyataan Pendaftaran ke Otoritas Jasa Keuangan}

Setelah memperoleh Perjanjian Pendahuluan Pencatatan Saham dari Bursa Efek Indonesia, perusahaan menyampaikan Pernyataan Pendaftaran dan dokumen pendukungnya kepada Otoritas Jasa Keuangan untuk melakukan penawaran umum saham. Dokumen pendukung yang diperlukan antara lain adalah prospektus. Kondisi keuangan dan kegiatan usaha perusahaan diungkapkan kepada publik melalui prospektus.

Sebelum mempublikasikan prospektus ringkas di surat kabar atau melakukan penawaran awal (bookbuilding), perusahaan harus menunggu izin dari Otoritas Jasa Keuangan (OJK). OJK akan memberikan pernyataan efektif setelah perusahaan menyampaikan informasi mengenai harga penawaran umum saham dan keterbukaan informasi lainnya. Bila Pernyataan Pendaftaran dinyatakan efektif, Perusahaan mempublikasikan perbaikan/tambahan informasi prospectus ringkas di surat kabar serta menyediakan prospektus bagi publik atau calon pembeli saham, serta melakukan penawaran umum.

\section{Penawaran Umum, Pencatatan dan Perdagangan Saham di Bursa Efek Indonesia.}

Masa penawaran umum saham kepada publik dapat dilakukan selama 1-5 hari kerja. Dalam hal permintaan saham dari Investor melebihi jumlah saham yang ditawarkan, maka perlu dilakukan penjatahan. Distribusi saham akan dilakukan kepada Investor pembeli saham secara elektronik melalui KSEI (tidak dalam bentuk sertifikat). 
Perusahaan menyampaikan permohonan pencatatan saham kepada Bursa disertai dengan bukti surat bahwa Pernyataan Pendaftaran telah dikatakan efektif oleh OJK, dokumen prospektus, dan laporan komposisi pemegang saham perusahaan. Bursa Efek Indonesia akan memberikan persetujuan dan mengumumkan pencatatan saham perusahaan dan kode saham perusahaan untuk keperluan perdagangan saham di Bursa. Kode saham ini akan dikenal Investor secara luas dalam melakukan transaksi saham perusahaan di Bursa Efek Indonesia.

\section{iii. Perbedaan Equity Crowdfunding dan Initial Public Offering (IPO)}

Pertama, pada Pasal 5 ayat (1) Peraturan Otoritas Jasa Keuangan Nomor 37/POJK.04/2018 diatur bahwa suatu penawaran saham oleh setiap Penerbit melalui Layanan Urun Dana bukan merupakan penawaran umum sebagaimana dimaksud dalam Undang-Undang Nomor 8 Tahun 1995 tentang Pasar Modal jika:

a. penawaran saham dilakukan melalui Penyelenggara yang telah memperoleh izin dari Otoritas Jasa Keuangan;

b. penawaran saham dilakukan dalam jangka waktu paling lama 12 (dua belas) bulan; dan

c. total dana yang dihimpun melalui penawaran saham paling banyak $\mathrm{Rp}$ 10.000.000.000,00 (sepuluh miliar rupiah).

Sehingga, perbedaan pertama antara keduanya yaitu Penyelenggara telah memperoleh izin dari Otoritas Jasa Keuangan, adanya pengaturan mengenai jangka waktu penawaran saham paling lama 12 (dua belas) bulan, serta batasan total dana yang dihimpun melalui penawaran saham yakni $\mathrm{Rp}$ 10.000.000,00 (sepuluh miliar rupiah).

Kedua, Undang-Undang Nomor 8 Tahun 1995 pada Pasal 1 ayat (22) mengatur bahwa suatu Perusahaan Publik adalah Perseroan yang sahamnya telah dimiliki sekurang-kurangnya oleh 300 (tiga ratus) pemegang saham dan memiliki modal disetor sekurang-kurangnya $\mathrm{Rp} \quad 3.000 .000 .000,00$ (tiga miliar rupiah) atau suatu jumlah pemegang saham dan modal disetor yang ditetapkan oleh Peraturan Pemerintah.
Sedangkan Penerbit berdasarkan pada Pasal 6 Peraturan Otoritas Jasa Keuangan Nomor 37/POJK.04/2018 bukan merupakan perusahaan publik sebagaimana dimaksud dalam Undang-Undang Nomor 8 Tahun 1995 tentang Pasar Modal jika:

a. Jumlah pemegang saham Penerbit tidak lebih dari 300 (tiga ratus) pihak; dan

b. Jumlah modal disetor Penerbit tidak lebih dari Rp 30.000.000.000 (tiga puluh miliar rupiah).

Sehingga, perbedaan kedua antara keduanya adalah Perusahaan Publik memiliki minimal 300 (tiga ratus) pemegang saham sedangkan Penerbit dalam Layanan Urun Dana maksimal memiliki 300 (tiga ratus) pemegang saham. Pada Perusahaan Publik, modal disetor minimal adalah Rp 3.000.000.000,00 (tiga miliar rupiah) tanpa batas maksimum, sedangkan pada Penerbit Layanan Urun Dana, modal disetornya ditentukan nilai maksimumnya, yaitu Rp 30.000.000.000,00 (tiga puluh miliar rupiah)

Ketiga, pada Undang-Undang Nomor 8 Tahun 1995 terdapat profesi penunjang pasar modal, yaitu:

1. Akuntan, yaitu akuntan yang telah memperoleh izin dari Menteri dan terdaftar di Bapepam.

2. Konsultan Hukum, yaitu ahli hukum yang memberikan pendapat hukum kepada pihak lain dan terdaftar di Bapepam.

3. Penilai, yaitu pihak yang memberikan penilaian atas aset perusahaan dan terdaftar di Bapepam.

4. Notaris, yaitu pejabat umum yang berwenang membuat akta autentik dan terdaftar di Bapepam.

5. Profesi lain yang ditetapkan dengan Peraturan Pemerintah.

Sedangkan pada Peraturan Equity Crowdfunding, tidak dikenal adanya Profesi Penunjang. Sehingga, sejumlah risiko seperti tidak diperolehnya dividen, saham yang tidak likuid, terjadi dilusi kepemilikan saham, hilangnya modal (capital loss), kegagalan operasional penyelenggara yang juga merupakan risiko yang terjadi di penawaran umum, memiliki risiko lebih besar terjadi pada skema Equity Crowdfunding karena tidak 
diminimalisir dengan keberadaan Profesi Penunjang.

Keempat, profil Initial Public Offering (IPO) mengedepankan perusahaan-perusahaan yang sudah dewasa dan besar, seperti salah satunya adalah persyaratan sekurangkurangnya sahamnya telah dimiliki oleh 300 (tiga ratus) pemegang saham dan adanya persyaratan sebagaimana tertuang pada Keputusan Menteri Keuangan Republik Indonesia No. 859/KMK.01/1989 tentang emisi efek di bursa dan peraturan pelaksanaan emisi dan perdagangan saham yang tercantum dalam keputusan BAPEPAM No. 011/PM/1987. Equity Crowfunding sebaliknya memberikan persyaratan-persyaratan yang lebih cocok untuk perusahaan kecil dan start up.

Kelima, berdasarkan Pasal 22 ayat (1)(3) Peraturan Otoritas Jasa Keuangan Nomor 37/POJK.04/2018, Penerbit dan Penyelenggara dalam Equity Crowdfunding melalui kesepakatan dapat menentukan berapa jumlah minimum dana yang harus diperoleh dalam penawaran saham melalui Platform Equity Crowdfunding, dan berbeda dengan perjanjian penjaminan emisi efek dalam suatu Initial Public Offering (IPO), penyelenggara sebagai penjamin emisi efek tidak memiliki suatu opsi tetap menjalankan fungsinya dengan komitmen terhadap jumlah minimum dana yang harus diperoleh.

\section{KESIMPULAN}

Berdasarkan paparan di atas, maka, meskipun konsep Equity Crowdfunding dan Initial Public Offering memiliki kesamaan, namun, terdapat beberapa hal pembeda antara keduanya. Pada Equity Crowdfunding, penawaran saham dilakukan melalui Penyelenggara yang telah memperoleh izin dari Otoritas Jasa Keuangan, dilakukan dalam jangka waktu paling lama 12 (dua belas) bulan dengan total dana yang dihimpun paling banyak Rp 10.000.000.000 (sepuluh miliar) rupiah. Jumlah pemegang saham Penerbit tidak lebih dari 300 (tiga ratus) pihak dan jumlah modal disetor Penerbit tidak lebih dari Rp 30.000.000.000 (tiga puluh miliar rupiah), sedangkan pada Initial Public Offering (IPO), jumlah pemegang saham minimal adalah 300 (tiga ratus) pihak dengan tanpa batasan maksimum modal disetor Penerbit.

\section{SARAN}

Dari profil risiko, Equity Crowdfunding memiliki risiko lebih tinggi daripada Initial Public Offering (IPO) karena tidak dilengkapi dengan Profesi Penunjang. Transaksi yang dilakukan sangat mengandalkan Platform Digital, maka dari itu, sangat penting untuk mmberikan persyaratan-persyaratan khusus terhadap Penyelenggara dan Pengguna dalam Equity Crowdfunding. Selanjutnya, Initial Public Offering (IPO) diperuntukkan untuk perusahaan yang sudah well established, sedangkan Equity Crowdfunding, sejak awal pembentukan peraturan, dibuat untuk membantu perusahaan kecil dan start up dalam memperoleh pendanaan.

\section{DAFTAR PUSTAKA}

Darmadji, Tjitono dan Hendy M. Fakhruddin. (2001). Pasar Modal Indonesia Pendekatan Tanya Jawab. Jakarta: Penerbit Salemba Empat.

Hariyani, Iswi dan Purnomo Serfianto. (2010). Buku Pintar Hukum Bisnis Pasar Modal. Cet.1. Jakarta: VisiMedia.

Raharjo, Sapto. (2006). Kiat Membangun Aset Kekayaan. Cet.2. Jakarta: Elex Media Komputindo.

Soekanto, Soerdjono dan Sri Mamudji. (2001). Penelitian Hukum Normatif: Suatu Tinjauan Singkat. Jakarta: PT RajaGrafindo Persada.

Indonesia. Undang-Undang No. 8 Tahun 1995 tentang Pasar Modal, Lembaran Negara Republik Indonesia (LNRI) No. 64 Tahun 1995, dan Tambahan Lembaran Negara (TLN) No. 3608.

$\begin{array}{llr}\text { Keputusan Menteri Keuangan } \\ \text { Republik } & \text { Indonesia } & \text { No. } \\ & \text { 859/KMK.01/1989 tentang Emisi } \\ \text { Efek di Bursa } & \\ \text { Keputusan Badan Pengawas Pasar } \\ \text { Modal No. 011/PM/1987 tentang } \\ \text { Pelaksanaan Emisi dan Perdagangan } \\ \text { Saham }\end{array}$


Otoritas Jasa Keuangan, Peraturan Otoritas Jasa Keuangan Nomor 37/POJK.04/2018 tentang Layanan Urun Dana Melalui Penawaran Saham Berbasis Teknologi Informasi (Equity Crowdfunding), Lembaran Negara Republik Indonesia (LNRI) No. 262 Tahun 2018, dan Tambahan Lembaran Negara (TLN) No. 6288.

Bursa Efek Indonesia. "Panduan IPO (Go Public),"

<https://www.idx.co.id/Portals/0/Stat icData/Information/ForCompany/Pan duan-Go-Public\%20_Dec-

2015.pdf>, diakses tanggal 7 Januari 2021.

Bursa Efek Indonesia. "Proses Go Public," http://www.idx.co.id/MainMenu/Edu cation/ProsesGoPublic/tabid/192/lan g/id-ID/language/id-ID/Default.aspx, diakses tanggal 7 Januari 2021.

Cambridge Online Dictionary. $<$ https://dictionary.cambridge.org/dic tionary/english/start-up>, diakses pada 16 Desember 2020 pukul 07.17 WIB.

Otoritas Jasa Keuangan. "Daftar Platform Equity Crowdfunding Yang Telah Mendapatkan Ijin dari OJK”, $<$ https://ojk.go.id/id/berita-dankegiatan/publikasi/Documents/Pages IDaftar-Platform-EquityCrowdfunding-yang-TelahMendapatkan-Izin-dari-OJK-Per-31Desember2019/Daftar\%20Platfrom\%20ECF\% 20yang\%20telah\%20berizin\%20per $\% 2031 \% 20$ Desember\%202019.pdf $>$, diakses tanggal 16 Desember 2020 